\title{
Role of Irisin Administration in Modulating Testicular Function in Adult Obese Albino Rats
}

\author{
REHAM H. IBRAHIM, M.D. and NANEES F. EL-MALKEY, M.D. \\ The Department of Physiology, Faculty of Medicine, Zagazig University, Zagazig, Egypt
}

\begin{abstract}
Background: Irisin, exercise-induced myokine, is known to improve obesity-induced metabolic disturbances by enhancing thermogenesis and increasing energy expenditure. Recent studies have reported that irisin promoted cell proliferation and protected cells from apoptosis. However, the effects of irisin on testicular function in obese rats is still to be investigated.
\end{abstract}

Aim of the Study: This study was designed to explore the probable effects of irisin treatment on modulating the adverse effects of obesity on testicular functions with a trial to clarify some of the possible underlying mechanisms.

Material and Methods: Thirty adult male wistar albino rats $(200 \pm 30 \mathrm{~g})$ were divided equally into 3 groups, group (I): Saline-vehicle treated normal fed group, group (II): Salinevehicle treated rats were fed a High Fat Diet (HFD) for 10 weeks. Group (III): Irisin treated HFD-fed rats for 10 weeks and irisin was injected subcutaneously (150 d d for 4 weeks). Rats were weighed and serum levels of glucose, insulin, lipid profile, FSH, LH, estradiol \& testosterone levels, epididymal sperm count and motility, testicular Malondialdhyde (MDA) level, Superoxide Dismutase (SOD), Catalase (CAT), Glutathione Peroxidase ( $\left.\mathrm{GP}_{\mathrm{X}}\right)$ activities, testicular and epidydimal fat weights were estimated. Testicular histopathological study was done as well.

Results: There was a significant increase in the Body Mass Index (BMI) together with deterioration of metabolic, gonadal functions and testicular oxidant/antio-oxidant system in group (II), while exogenous irisin administration in group (III) resulted in: Significant decrease in BMI, insulin resistance with improvement in lipid profile, significant increase in serum FSH, LH \& testosterone, sperm count and motility in male rats. Together with marked improvement in the testicular histoarchitecture. Additionally, there was a significant increase in testicular SOD, CAT \& GP $\mathrm{X}$ activities. However, it significantly decreased testicular MDA level.

Conclusions: It could be suggested that irisin has a potential positive role against obesity-induced testicular dysfunction, which may be due to its role in maintenance of glucose \& insulin homeostasis, its antioxidant properties and/ or maintenance of gonadal hormonal function via indirect and/or direct effects on the gonads.

Correspondence to: Dr. Nanees Fouad,

E-Mail: nanees fouad@yahoo.com
Key Words: Irisin - Obesity - Testicular function.

\section{Introduction}

OBESITY is a worldwide health problem that could lead to disturbance in both male and female fertility [1]. It has been reported that obesity can affect males fertility by decreasing the number of spermatozoids [2]. Furthermore, it has been seen that obese males frequently show a low testosterone (T) and a high estradiol levels [3]. Interestingly, this hormonal disturbance was found to be proportional to the degree of obesity [4]. Moreover, Insulin Resistance (IR) and Oxidative Stress (OS) could play a vital role in explaining how excess body fat interferes with the reproductive functions [1].

Irisin, a novel myokine secreted by skeletal muscle, has been first discovered and reported by Bostrom et al., [5] . It is synthesized by hydrolysis of fibronectin type III domain-containing protein 5 (FNDC5) [5]. Irisin has a critical role in improving insulin sensitivity and enhancing cognitive capacity during the regulation of obesity [6]. It causes overexpression of Uncoupling Protein-1 (UCP1) in adipose tissue resulting in the browning of white adipocytes participating in the treatment of obesity [7]. Despite irisin plays an important role in energy homeostasis, its biological actions on reproduction remain unclear $[\mathbf{8 , 9}]$.

As male factor can account for a high rate of infertility [10], the purpose of the present study was to assess the possible effect of irisin treatment on gonadal functions in obese adult male albino rats and to clarify some of the possible involved mechanisms.

\section{Material and Methods}

From 1 st of October 2017 till the end of January 2018, thirty adult male wistar albino rats (weighing 
$200 \pm 30 \mathrm{~g}$ ) were included in the present work after the approval of the Institutional Research Board of Faculty of Medicine-Zagazig University.

They were housed in room temperature and in natural dark/light cycles. They had free access to food and water. After a week of acclimatization, the animals were divided randomly into 3 equal groups:

Group (I): Control rats received standard diet (14\% fat, $54 \%$ carbohydrate, $32 \%$ protein and 3.02 calories/g) for 10 weeks, Group (II): Rats received High Fat Diet (HFD) (Faculty of Agriculture, Zagazig University) (60\% fat, $21 \%$ carbohydrate, $18 \%$ protein and 5.1 calories/g) for 10 weeks to induce obesity [11] and Group (III): The irisin treated rats; rats were fed HFD for 10 weeks and from the end of the 6 th week till the end of the experimental period, irisin (Sigma-Aldrich) was injected in a daily dose of $12 \mathrm{nmole} / \mathrm{kg}$ subcutaneously, each rat received 150 Lofprepared irisin solution in a concentration of $100 \mathrm{ng} / \mathrm{ml}[\mathbf{1 2 , 1 3}]$ Rats in the control and obese untreated groups received saline simultaneously.

Calculating Body Mass Index (BMI): It can be used as an indicator of obesity where the cutoff value of obesity $\mathrm{BMI}>0.68 \mathrm{~g} / \mathrm{cm}^{2}$. BMI=body weight $(\mathrm{g}) /$ length ${ }^{2}\left(\mathrm{~cm}^{2}\right)[14]$

\section{Blood collection:}

At the end of the intervention, the overnight fasting animals were sacrificed under light ether anesthesia, and blood samples were obtained by decapitation of all rats and were collected in clean plastic tubes for centrifugation. Serum was stored frozen at $-20^{\circ} \mathrm{C}$ until assayed.

\section{1- Serum biochemical analysis:}

A- Glucose level by spectrophotometer at $546 \mathrm{~nm}$ according to Tietz [15] using glucose enzymatic (GOD-PAP)-liquizyme Kits. (Biotechnology, Egypt) and insulin level using rat insulin Enzyme-Linked Immunosorbent Assay (ELISA) kit (RAB0904, Sigma-Aldrich Chemie GmbH, U.S.A) according to Starr et al., [16]

Calculation of homeostasis model assessment of IR (HOMA-IR)=Insulin ( $\mathrm{U} / \mathbf{L} \mathbf{L}) \mathrm{X}$ glucose $(\mathrm{mg} / \mathrm{dl}) / 405$ [17].

B- Luteinizing Hormone (LH), Estradiol (E2), testosterone [15] and Follicle-Stimulating Hormone (FSH) levels [18] using the corresponding rat ELISA kits (Cat: 2011-11-0180, 2011-110175, 2011-11-5126 and 2011-11-0183; respectively. Shanghai Sunred Biological Technology, China).
C- Total Cholesterol (TC), Triglyceride (TG) and High Density Lipoproteins (HDL) levels using the corresponding rat ELISA kit (Cat: 8-B14002011-11-0255, 8-C-1150, BioSource Europe S.A.-Rue de l'Industrie, Nivelles-Belgium and 2011-11-0255, Shanghai Sunred biological technology, China; respectively) [15]

D- Low Density Lipoproteins (LDL) levels was calculated as follows: LDL=TC-HDL-TG/5 [19].

\section{2- Testicular examination:}

Midline incision along the abdominal wall was done, the testes were quickly removed, washed in cold physiologic saline, and were dried with filter paper. The weight of the right testes were measured using an electronic balance, then they were processed for histopathological studies and the left one was homogenised for biochemical estimations of oxidant/antioxidant enzyme activities.

- Preparation of testis homogenate: The testes were sliced and homogenized in cold $50 \mathrm{mM}$ phosphate buffer ( $\mathrm{pH} 7.0$ ) containing $0.1 \mathrm{mM}$ EDTA to give $10 \%$ homogenate (w/v). The homogenates were centrifuged at 1000r.p.m. for $10 \mathrm{~min}$. The supernatants were separated and used for enzymes activity assays and lipid peroxidation determination [20].

- Testicular antioxidant system evaluation: Assay of Superoxide Dismutase (SOD) activity according to the method described by Kakkar et al., [21], assay of Catalase (CAT) activity according to the method described by Luck [22], assay of Glutathione Peroxidase $\left(\mathrm{GP}_{\mathrm{X}}\right)$ activity according to the method described by Reddy et al., [23] and assay of Malondialdhyde (MDA) level according to the method described by Ohkawa et al., [24], using spectrophotometer at 560nm, 240nm, 430nmand 535nm; respectively (Germany).

- Testicular histopathological examination: Testes were then fixed in $10 \%$ formaldehyde in fresh alcoholic bouin's fluid for 8 hours, and then processed and embedded in paraffain wax, sectioned at 5 mickness, and stained in hematoxylin-eosin. The sections were examined under a light microscope and the general histological appearance was assessed [25]

3- Spermatic parameters analysis: The right epididymis of each rat was dissected, removed and minced in $2 \mathrm{ml}$ of Hank's buffer salt solution at $37^{\circ} \mathrm{C}$ [26]. After $5 \mathrm{~min}$ incubation at $37^{\circ} \mathrm{C}$, the cauda epididymis sperm count was analyzed using the standard hemocytometric method. The percentage of sperm motility was calculated 
using the number of live sperm cells over the total number of sperm cells [27]

Statistical analysis: Statistical tests were performed using the Statistical Package for Social Sciences (SPSS), Version 18.0 (SPSS, Chicago, IL, USA) for Windows 7. All data are expressed as the means \pm Standard Error of the Mean (S.E.M). Multiple groups comparisons were carried using one-way ANOVA, followed by post hoc test, and $p<0.05$ was considered to be statistically significant.

\section{Results}

The present study showed that HFD induced significant increase in BMI, serum glucose, insulin and calculated HOMA-IR $(p<0.001)$ in group (II) when compared with control group. Moreover, there was a significant increase in serum TC, TG, LDL $(p<0.001)$ with a significant decrease in serum HDL $(p<0.01)$ in the same group in comparison to control group.

In addition, treatment of obese rat with exogenous irisin led to a significant decrease in BMI, glucose, insulin, HOMA-IR, TC, TG, LDL ( $p$ $<0.001$ ) when compared to group (II). However, these parameters were significantly increased when compared with control group ( $p<0.001)$, accompanied with a significant increase in HDL $(p<0.01)$ when compared with group (II), while, this change was insignificant when compared with control group $(p>0.05)$ (Table 1).

Table (1): Metabolic parameters in all groups.

\begin{tabular}{llll}
\hline \multicolumn{1}{c}{ Groups } & Group I & \multicolumn{1}{c}{ Group II } & Group III \\
Parameters & & & \\
\hline BMI $\left(\mathrm{g} / \mathrm{cm}^{2}\right)$ & $0.52 \pm 0.01$ & $0.81 \pm 0.02 *$ & $0.63 \pm 0.02 * \#$ \\
Glucose $(\mathrm{mg} / \mathrm{dl})$ & $86.8 \pm 2.08$ & $216.9 \pm 8.16^{*}$ & $147.6 \pm 6.54^{*} \#$ \\
Insulin $(\mu \mathrm{IU} / \mathrm{ml})$ & $14.5 \pm 0.58$ & $30.3 \pm 0.94^{*}$ & $18.4 \pm 0.64 * \#$ \\
HOMA-IR & $3.08 \pm 0.07$ & $16.35 \pm 1.03 *$ & $6.65 \pm 0.25^{*} \#$ \\
TC $(\mathrm{mg} / \mathrm{dl})$ & $95.2 \pm 1.81$ & $191.1 \pm 4.89^{*}$ & $155.8 \pm 2.59^{*} \#$ \\
TG $(\mathrm{mg} / \mathrm{dl})$ & $55.1 \pm 2.62$ & $108.1 \pm 2.37 *$ & $78.6 \pm 2.40^{*} \#$ \\
LDL $(\mathrm{mg} / \mathrm{dl})$ & $66.98 \pm 1.59$ & $156.13 \pm 4.63^{*}$ & $122.98 \pm 1.74 * \#$ \\
HDL $(\mathrm{mg} / \mathrm{dl})$ & $17.2 \pm 0.99$ & $13.35 \pm 0.68^{*}$ & $17.1 \pm 0.78 \#$ \\
\hline
\end{tabular}

*: Sig vs. group (I).
\#: Sig vs. group (II).

As regard to serum hormonal profile, our results showed a significant reduction in FSH $(p<0.001)$, LH $(p<0.01)$ and T $(p<0.001)$ levels accompanied by a significant increase in E2 $(p<0.001)$ level in group (II) when compared with control group. However, treatment of obese rats with exogenous irisin in group (III) revealed a significant increase in FSH $(p<0.001), \mathrm{LH}(p<0.05)$ and T $(p<0.001)$ levels with a significant decrease in E2 $(p<0.001)$ level in comparison to those of group (II).
In addition, serum $\mathrm{T}$ was significantly low in irisin-treated group when compared with control group $(p<0.05)$. However, serum E2 was significantly high in the same group in comparison to control group $(p<0.001)$. While, there was an insignificant change in $\mathrm{FSH}$ and $\mathrm{LH}$ after treatment with irisin in group (III) in comparison to control group $(p>0.05)$ (Table 2).

Table (2): Serum FSH, LH, T, E2 levels, right testicular, epididymal fat weights, sperm count and motility of all studied groups.

\begin{tabular}{|c|c|c|c|}
\hline Parameters & Group (I) & Group (II) & Group (III) \\
\hline $\mathrm{FSH}(\mu \mathrm{IU} / \mathrm{ml})$ & $0.33 \pm 0.22$ & $0.16 \pm 0.01 *$ & $0.29 \pm 0.02 \#$ \\
\hline $\mathrm{LH}(\mu \mathrm{IU} / \mathrm{ml})$ & $1.5 \pm 0.12$ & $1.03 \pm 0.07 *$ & $1.3 \pm 0.11 \#$ \\
\hline $\mathrm{T}(\mathrm{ng} / \mathrm{ml})$ & $4.2 \pm 0.28$ & $1.8 \pm 0.13 *$ & $3.5 \pm 0.13 * \#$ \\
\hline $\mathrm{E} 2(\mathrm{Pg} / \mathrm{ml})$ & $5.7 \pm 0.35$ & $12.1 \pm 0.60 *$ & $8.1 \pm 0.40^{*} \#$ \\
\hline Testicular weight (g) & $1.6 \pm 0.87$ & $0.9 \pm 0.17 *$ & $1.4 \pm 0.79 \#$ \\
\hline epididymal fat weights $(\mathrm{g})_{3}$ & $3.8 \pm 0.15$ & $5.7 \pm 0.17 *$ & $4.4 \pm 0.14 * \#$ \\
\hline Sperm count (million $/ \mathrm{mm}^{3}$ ) & $53.4 \pm 1.53$ & $20.9 \pm 0.8^{*}$ & $38.8+0.69 * \#$ \\
\hline Sperm motility $(\%)$ & $76 \pm 1.18$ & $25.9 \pm 1.44 *$ & $54.5 \pm 1.57 * \#$ \\
\hline
\end{tabular}

Moreover, our results showed a significant increase in epididymal fat weight $(p<0.001)$ accompanied by significant decrease in testicular weight (Table 2), epididymal sperm count and motility $(p<0.001)$ in HFD-fed rats in comparison to control group. Interestingly, irisin treatment caused a significant reduction in epididymal fat weights $(p<0.001)$ together with a significant increase in testicular weight (Table 2), epididymal sperm count and motility $(p<0.001)$ in group (III) when compared with group (II) (Table 2).

However, there was a significant increase in epididymal fat weights $(p<0.05)$ accompanied with a significant decrease in epididymal sperm count and motility $(p<0.001)$ in group (III) when compared with group (I). While, there was an insignificant change in testicular weight between both groups $(p>0.05)$ (Table 2).

Table (3): Testicular oxidant and anti-oxidant enzymes level in all groups.

\begin{tabular}{llll}
\hline \multicolumn{1}{c}{ Groups } & Group (I) & Group (II) & Group (III) \\
& & & \\
\hline Marameters & $113 \pm 1.53$ & $194 \pm 3.08^{*}$ & $128.6 \pm 1.38^{* \#}$ \\
SOD (nmol/gm tissue) & $73.6 \pm 3.80$ & $35.3 \pm 2.19 *$ & $65.3 \pm 1.81^{* \#}$ \\
CAT activity (U/mg protein) (U/mg protein) & $19.05 \pm 0.82$ & $7.85 \pm 0.36 *$ & $16.7 \pm 0.40 * \#$ \\
GPX activity (U/mg protein) & $24.5 \pm 0.64$ & $14.6 \pm 0.62 *$ & $22.04 \pm 0.82 \#$ \\
\hline
\end{tabular}

*: Sig vs. group (I). \#: Sig vs. group (II).

Considering oxidant/antioxidant enzymes, the result of the present work showed a significant increase in testicular MDA level with a significant reduction in testicular SOD, CAT and GP $\mathrm{X}$ activity 
$(p<0.001)$ in HFD-fed rats in comparison to control group (Table 3 ).

However, irisin treatment significantly reduced testicular MDA level $(p<0.001)$ which was accompanied with a significant elevation in in testicular SOD, CAT and GPX activity $(p<0.001)$ in group (III) when compared with group (II). Additionally, in group (III) testicular MDA level was significantly elevated $(p<0.001)$ when compared with group (I).

While, testicular SOD, CAT activity were significantly lowered than those of group (I) $(p<0.05$ and $p<0.01$; respectively) with an insignificant change in Testicular GPX activity between the same groups $(p>0.05)$ (Table 3$)$.

In respect to the histopathological studies, testicular sections in HFD-fed rats showed atrophy in the walls of seminiferous tubules with reduction of sperm Lineage cells. Moreover, walls of tubules showed destruction of sertoli cells with increased thickness of the basement membrane Fig. (2). However, exogenous irisin treatment in group (III) induced a marked improvement in testicular histoarchitecture Fig. (3).

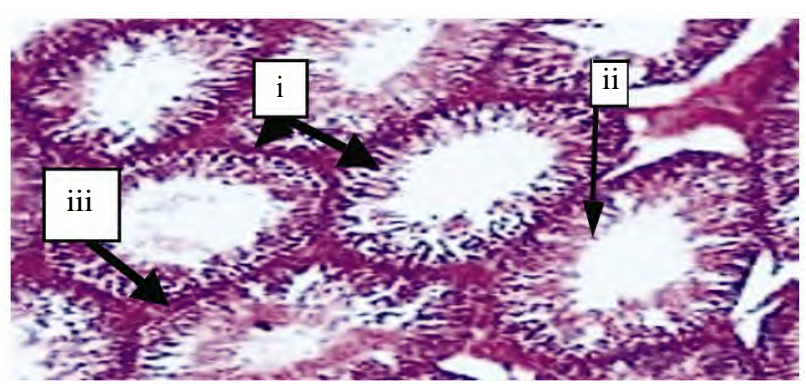

Fig. (1): Light microscopic picture of isolated rat testicular tissue in group I showing: Normal testicular tissue with uniform seminiferous tubules (i) lined by normal layers of spermatogenic cells (ii) with normal thickness basement membrane (iii) (H \& E X200).

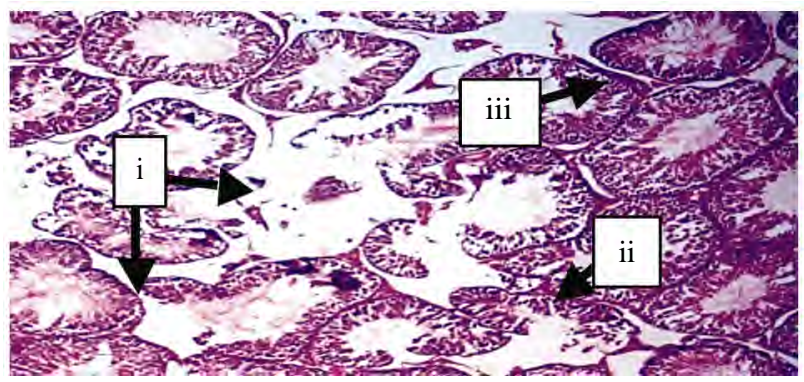

Fig. (2): Light microscopic picture of isolated rat testicular tissue in group II showing: (i) Marked atrophy in the wall of seminiferous tubules with destruction of sertoli cells (ii) and reduction of sperm Lineage cells. Irregular and thick basement membrane (iii) $(\mathrm{H} \&$ E X200)

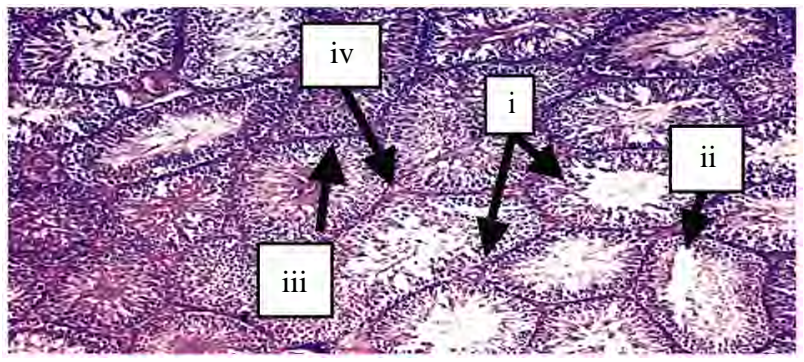

Fig. (3): Light microscopic picture of isolated rat testicular tissue in group III showing seminiferous tubules which were nearly equal in size and shape with mature spermatozoids in the lumen (i), and normal sertoli cells (ii). Nearly normal thickness of the basement membrane (iii).

\section{Discussion}

Previous studies have shown a direct relationship between obesity and infertility with an association between metabolic disturbances and hormonal dysregulation $[\mathbf{1 , 2 8}]$

After its discovery in 2012, irisin, a novel myocytokine was given a great therapeutic potential for the treatment of obesity and metabolic syndrome [5] . Recently, irisin was reported to regulate body weight, insulin sensitivity, and glucose homeostasis [29]. So it may be helpful in management of detrimental effect of obesity on testicular function.

The results of the present study revealed that HFD feeding of rats for 10 weeks resulted in a significant increase in BMI, blood glucose, insulin and HOMA-IR when compared with that of control rats which realized the successful establishment of a rat model of obesity with IR.

Moreover, our results revealed that, HFDinduced obesity had negatively alter testicular function in adult rats, as we reported a significant reduction in serum levels of $\mathrm{LH}, \mathrm{FSH}, \mathrm{T}$, and elevation of serum E2 levels accompanied by marked reduction in epididymal sperm count and motility together with a significant decrease in testicular weight, and a significant increase in epididymal fat, in addition to atrophy in the walls of seminiferous tubules, reduction of sperm Lineage cells, destruction of sertoli cells and increased thickness of the basement membrane in the histopathological studies of testicular sections in HFD group when compared with control group. These findings are supported by the findings of other investigators in both animals and humans $[30,31]$

Interestingly, in case of obesity increased conversion of $\mathrm{T}$ to estradiol in the adipose tissue might contribute to decreased plasma T concentrations 
leading to secondary hypogonadism [32]. In addition, as estrogen receptors are present in hypothalamic nuclei and pituitary gonadotropes, so increased circulating E2 level leads to suppression of the hypothalamic-pituitary axis affecting gonadotrophin releasing hormone $(\mathrm{GnRH})$ pulsing and resulting in subclinical hypogonadotropic hypogonadism [33]. Other authors also suggested that estradiol could have a direct effect on testicular environment altering spermatogenesis via degeneration of Leydig cells [34]

It is worth saying that insulin is considered an important factor that plays a regulatory role in reproductive function as $\mathrm{GnRH}$-expressing neurons can increase the expression of GnRH in response to insulin stimulation via insulin receptors by increasing in the expression of the transcriptional factor (c-fos) [35]. However, it has been suggested that obese patients with IR have a diminished sensitivity to insulin action in the hypothalamuspituitary-gonadal axis altering $\mathrm{GnRH}$ release which subsequently impair testicular steroidogenesis leading to decreased circulating $\mathrm{T}$ concentrations [36], which provides an evidence that high insulin levels with IR may play an important role in infertility in obese males [37].

The present study showed that exogenous irisin improved spermatogenic activity, in the form of significant increase in sperm count and motility together with a significant increase in testicular weight and decrease in epididymal fat weight. Moreover, it caused improvement in hormonal profile, in addition, our findings are Supported by the marked improvement in testicular histoarchitecture in group (III) in comparison to obese non treated rats.

The present study tried to explain the possible involved mechanisms through which irisin improved the spermatogenic activity. It was noticed that irisin decreased BMI and IR as proved by significant reduction in serum glucose, insulin and HOMA-IR in group (III) in comparison to group (II) which was in line with the observations of Xin et al., [38] who suggested that irisin can reduce IR by increasing glucose uptake accompanied with reduced gluconeogenesis in the liver.

Furthermore, it could also increase acetyl-CoA carboxylase- $\beta$ phosphorylation in skeletal muscle increasing fatty acid oxidation, along with an increase in mitochondrial Ucp1 expression in the epididymal adipose tissue leading to increase in energy expenditure, oxygen consumption and enhancing basal metabolism via browning of white adipose tissue [38]
Moreover, mitogen-activated protein kinase (AMPK) in skeletal muscle is an important regulatory molecule for lipid metabolism, as the increase in their phosphorylation can improve glucose intake and energy metabolism in the body [39]. Interestingly, Lee et al., [40] reported that irisin can activate AMPK in skeletal muscle, promoting fatty acid oxidation, and alleviate the occurrence of metabolic disorders. Additionally, Hou et al., [41] noticed that treatment of HFD mice with irisin increased adiponectin significantly, which is known to improve insulin sensitivity by increasing fatty acid oxidation and energy expenditure [42].

Additionally, in animal studies, researchers suggested a link between dyslipidemia and infertility, as they reported that hypertriglyceridemia and high cholesterol may decrease sperm acrosome reaction kinetics, and Leydig and Sertoli cell secretory capacity $[43,44]$. In the present study, irisin treatment decreased total cholesterol, LDL and total triglycerides, these findings were in line with what reported by Oelmann et al., [45] who noticed that an improved lipid profile in association with irisin. As there were inverse associations between irisin concentrations and total, LDL cholesterol as well as triglycerides. Providing another mechanism by which irisin molecule could improve testicular function in obese subjects.

In addition, irisin may improve hormonal profile through a direct stimulatory effect on GnRH release, this was reported by the observation of Jiang et al., [8] who noticed that irisin may serve as a novel intra-pituitary factor maintaining gonadotropins gene expression and increasing their mRNA levels, providing another mechanism for improving testicular function in this work.

Furthermore, our results showed a significant elevation in the testicular MDA level accompanied with a significant reduction of testicular antioxidant enzymes CAT, SOD and GPX activities in obese rats (group II) in comparison to control group, it was noted that excess adiposity is associated with systemic pro-inflammatory state [46], increased OS and Reactive Oxygen Species (ROS) production [47].

Interestingly, it was established also that hyperglycemia elicits an increase in ROS production [48]. As testicular tissues are highly rich in polyunsaturated fatty acid content of sperm membranes, testicular tissues and spermatozoa are very sensitive to ROS attack and lipid peroxidation [49]. Moreover, Henkel [50] explained OS in the epididymis by excess fat deposition in the heads of the epididy- 
midis, with reduction in the antioxidant system which leads to increased free radicals production that could induce genotoxicity by initiating sperm DNA denaturation and fragmentation and limiting DNA repair [51]

Additionally, Ibrahim et al., [52] noticed the increased apoptosis mediated by OS in the epididymis of obese rats could have an impact on the epididymal function, resulting in a low sperm count, viability and motility.

In the present study, rats treated with irisin showed reduced OS state that was proved by the significant reduction in MDA and increase in testicular antioxidant enzymes CAT, SOD and GP ${ }_{X}$ activities in comparison to obese non treated rats. In line with our findings, irisin was suggested to have antioxidant role as it was reported to increase the expression of antioxidant enzymes in vascular endothelial cells [53] and pancreatic $\beta$ cells [54] by inhibiting OS-induced activation of the Protein kinase $\mathrm{C}-\beta /$ /nicotinamide adenine dinucleotide phosphate oxidase (PKC- $\beta$ /NADPH) and nuclear factor kappa- $\beta$ /inducible Nitric oxide synthase (NF- $\kappa \mathrm{B} / \mathrm{iNOS}$ ) signaling pathways in high glucose/ high fat fed rats.

It is worth saying that OS stimulates cytokines secretion as interleukin- $1 \beta$ and tumour necrosis factor- $\alpha$ (TNF- $\alpha)$ by macrophages and other inflammatory cells which affect both steroidogenesis and spermatogenesis [55]. Interestingly, Hou et al., [41] and Mazur-Bialy et al., [56] noticed that irisin has a significant suppressive effect on NF $\kappa \mathrm{B}$ activity and suggested that irisin may have an antiinflammatory effect, counteracting inflammatory cytokines such TNF as and interleukins.

Moreover, we suggested that irisin could possibly protect the testicular germ cells against the adverse effects of obesity and accelerates testicular regenerative processes in this condition via its important role in the down-regulation the proapoptotic proteins and up-regulation of the antiapoptotic proteins $[\mathbf{5 4 , 5 7 ]}$.

Furthermore, another possible mechanism by which irisin could enhance the rate of total sperm motility is its ability to increase intracellular $\mathrm{Ca}^{2+}$ [58], as Marquez et al., [59] stated that elevation of intracellular $\mathrm{Ca}^{2+}$ can hyperactivate sperm motility which is essential for fertilization.

\section{Conclusion:}

Irisin may have a protective effect against HFDinduced testicular damage as treatment of obese rats with irisin can reverse these detrimental effects by improving spermatogenesis and steroidogenesis possibly due to its direct and/or indirect beneficent effects on insulin resistance, Oxidative stress and hypophyseal-testicular hormonal axis providing a new approaches for the treatment of metabolic and reproductive disorders complicating obesity.

Further studies are needed to validate the mechanisms of irisin signaling pathway on testicular spermatogenic function.

\section{Acknowledgement:}

To Professor/Hayam Rashid, Pathology Department, Faculty of Medicine, Zagazig University for performing testicular histopathological studies.

\section{References}

1- DAG Z.O. and DILBAZ B.: Impact of obesity on infertility in women. J. Turk. Ger. Gynecol. Assoc., 16 (2): 111-7, 2015.

2- KATIB A.: Mechanisms linking obesity to male infertility. Cent. European J. Urol., 68 (1): 79-85, 2015.

3- PAULI E.M., LEGRO R.S., DEMERS L.M., KUNSELMAN A.R., DODSON W.C. and LEE P.E.: Diminished Paternity and Gonadal Function with Increasing Obesity in Males. Fertil Steril., 90 (2): 346-51, 2008.

4- ROSENBLATT A., FAINTUCH J. and CECCONELLO I.: Abnormalities of reproductive function in male obesity before and after bariatric surgery-a comprehensive review. Obesity Surgery, 25 (7): 1281-92, 2015.

5- BOSTROM P., WU J., JEDRYCHOWSKI M.P., KORDE A., YE L., LO J.C., RASBACH K.A., BOSTRÖM E.A., CHOI J.H., LONG J.Z., KAJIMURA S., ZINGARETTI M.C., VIND B.F., TU H., CINTI S., HOJLUND K., GYGI S.P. and SPIEGELMAN B.M.: A PGC1- $\alpha$-dependent myokine that drives brown-fat-like development of white fat and thermogenesis. Nature, 481: 463-8, 2012.

6- PERAKAKIS N., TRIANTAFYLLOU G.A., FERNÁNDEZ-REAL J.M., HUH J.Y., PARK K.H., SEUFERT J. and MANTZOROS C.S.: Physiology and role of irisin in glucose homeostasis. Nature Reviews Endocrinology, 13: 324-37, 2017.

7- ZHANG G., SUN Q. and LIU C.: Influencing factors of thermogenic adipose tissue activity. Front. Physiol., 7: 29-40, 2016.

8- JIANG Q., ZHANG Q., LIAN A. and XU Y.: Irisin stimulates gonadotropins gene expression in tilapia (Oreochromis niloticus) pituitary cells. Animal Reproduction Science, 185: 140-7, 2017.

9- BASTU E., ZEYBEK U., GUREL GUREVIN E., YÜKSEL OZGOR B., CELIK F., OKUMUS N., DEMIRAL I., DURAL O., CELIK C., BULUT H., ILKAY ARMUTAK E., BAYSAL B., BUYRU F. and YEH J.: Effects of Irisin and Exercise on Metabolic Parameters and Reproductive Hormone Levels in High-Fat Diet-Induced Obese Female Mice. Reprod Sci., 25 (2): 281-91, 2018.

10- AJAH L.O., OZUMBA B.C., ONOH R.C., EZEONU P.O., IYOKE C.A. and EZEOME I.V.: Seminal fluid 
features of male partners of infertility patients in southeast Nigeria. Afr. J. Med. Health Sci., 15: 86-91, 2016.

11-FRAULOB J.C., OGG-DIAMANTINO R., FERNANDESSANTOS C., AGUILA M.B. and MANDARIM-DELACERDA C.A.: A Mouse Model of Metabolic Syndrome: Insulin Resistance, Fatty Liver and Non-Alcoholic Fatty Pancreas Disease (NAFPD) in C57BL/6 Mice Fed a High Fat Diet. J. Clin. Biochem. Nutr., 46 (3): 212-23, 2010.

12- TANG H., YUA R., LIU S., HUWATIBIEKE B., LI Z. and ZHANG W.: Irisin Inhibits Hepatic Cholesterol Synthesis via AMPK-SREBP2 Signaling. E. Bio. Medicine, 6: 139-48, 2016.

13- SALEH B.O., MAJEED M.J. and OREABY G.M.: Irisin impact as a medication that ameliorate and hinder the development of insulin resistance associated disorders without regular exercise (experimental study). IOSRJDMS, 13 (9): 28-35, 2014.

14- NOVELLI E., DINIZ Y., GALHARDI C., EBAID G., RODRIGUES H., MANI F., FERNANDES A., CICOGNA A. and NOVELLI F.J.: Anthropometrical parameters and markers of obesity in rats Laboratory Animals Ltd. Laboratory Animals, 41: 111-9, 2007.

15- TIETZ N.W., COOK T. and McNIVEN M.A.: Clinical Guide to Laboratory Tests, 3 rd edition. Pbl. W.B. Saunders, Co., Philadelphia, pp. 509-12, 1995.

16- STARR J.I., MAKO M.E., JUHN D. and RUBENSTEIN A.H.: Measurement of serum pro-insulin-like material: Cross reactivity of porcine and human proinsulin. J. Lab. Clin. Med., 91: 691-2, 1978.

17- MATTHEWS D.R., HOSKER J.P., RUDENSKY A.S., NAYLOR B.A., TREACHER D.F. and TURNER R.C.: Homeostasis model assessment: Insulin resistance and beta-cell function from fasting plasma glucose and insulin concentrations in man. Diabetologia, 28: 412-9, 1985.

18- REBAR R.W., MORANDINI I.C., PETZE J.E. and ERICKSON G.F.: Hormonal basis of reproductive defects in athymic mice: Reduced gonadotropins and testosterone in males. Biol. Repro., 5: 1267-76, 1982.

19- FRIEDWALD W.T., LEVY R.I. and FREDRICKSON D.S.: Estimation of the concentration of low-density lipoprotein cholesterol in plasma, without use of the preparative ultracentrifuge. Clin. Chem., 18: 499-502, 1972.

20- SCHLORFF E.C., HUSAIN K. and SOMANI S.M.: Dose and time dependent effects of ethanol on antioxidant system in rat testes. Alcohol., 18: 203-14, 1999.

21- KAKKAR P., DAS B. and VISWANATHAN P.N.: A modified spectrophotometric assay of superoxide dismutase. Indian J. Biochem. Biophys., 21: 130-2, 1984.

22- LUCK H.: Methods in Enzymatic Analysis. Academic Press, 2: 885-90, 1974.

23- REDDY K.P., SUBHANI S.M., KHAN P.A. and KUMAR K.B.: Effect of light and benzyl adenine on dark-treated growing rice leaves, II changes in peroxidase activity. Plant. Cell Physiol., 24: 987-94, 1995.

24- OHKAWA H., OHISHI N. and YAGI K.: Assay for lipid peroxides in animals and tissue by thiobarbituric acid reaction. Anal. Biochem., 95: 351-8, 1979.
25- IDRIS M.H., BUDIN S.B., OSMAN M. and MOHAMED J.: Protective role of hibiscus sabdariffa calyx extract against streptozotocin induced sperm damage in diabetic rats. Excli Journal, 11: 659-69, 2012.

26- KHAKI A., NOURI M., FATHIAZAD F., AHMADIASHTIANI H.R., RASTGAR H. and REZAZADEH: Beneficial effects of quercetin on sperm parameters in streptozotocin-induced diabetic male rats. Phytother. Res., 24 (9): 1285-91, 2009.

27- MURTHY N.V., WRAY S.R., MELVILLE G.N., WYNTER H.H., RAM N.V. and HARAN N.V.: Testicular function in rats following immobilization stress. Int. J. Gynaecol. Obstet., 22: 297-9, 1988.

28- ALVAREZ-CASTRONER P., SANGIAO-ALVARELLOS S., BRANDON S. and CORDIDO F.: Endocrine function in obesity. Endocrinol. Nutr., 58 (8): 422-32, 2011.

29- HUH J.H., AHN S.V., CHOI J.H., KOH S.B. and CHUNG C.H.: High Serum Irisin Level as an Independent Predictor of Diabetes Mellitus. A Longitudinal Population-Based Study. Medicine (Baltimore), 95 (23): e3742, 2016.

30- IBRAHIM M.H., SELIM S.A., ABD-ALALEEM D.I. and AL-SAYED R.M.: Effect of Obestatin on Gonadal Functions in High Fat-fed Albino Rats. Basic Sciences of Medicine, 3 (3): 43-59, 2014.

31- YAN W.J., MU Y., YU N., YI T.L., ZHANG Y., PANG X.L., CHENG D. and YANG J.: Protective effects of metformin on reproductive function in obese male rats induced by high-fat diet. J. Assist. Reprod. Genet., 32 (7): 1097-104, 2015.

32- WANG C., JACKSON G., JONES T.H., MATSUMOTO A.M., NEHRA A., PERELMAN M.A., SWERDLOFF R.S., TRAISH A., ZITZMANN M. and CUNNINGHAM G.: Low testosterone associated with obesity and the metabolic syndrome contributes to sexual dysfunction and cardiovascular disease risk in men with type 2 diabetes. Diabetes Care, 34 (7): 1669-75, 2011.

33- CABLER S., AGARWAL A., FLINT M. and DU-PLESSIS S.S.: Obesity: Modern man's fertility nemesis. Asian J. Androl., 12: 1-10, 2010.

34- LEAVY M., TROTTMANN M., LIEDL B., REESE S., STIEF C., FREITAG B., BAUGH J., SPAGNOLI G. and SKÖLLE S.: Effects of Elevated $\beta$-Estradiol Levels on the Functional Morphology of the Testis-New Insights. Sci. Rep., 7: 39931, 2017.

35- VIEN H., LEE Y., LEO T., LEE O. and CHOW B.K.C.: Gonadotropin-releasing hormone: Regulation of the $\mathrm{GnRH}$ gene. FEBS Journal, 275: 5458-78, 2008.

36- CALDAS A.D.A., PORTO A.L., CASULARI Da MOTTA L.D. and CASULARI L.A.: Relationship between insulin and hypogonadism in men with metabolic syndrome. Arq. Bras. Endocrinol. Metab., 53 (8): 1005-11, 2009.

37- KELSEY M.M., BJORNSTAD P., McFANN K. and NADEAU K.: Testosterone concentration and insulin sensitivity in young men with type 1 and type 2 diabetes. Pediatr. Diabetes, 7 (3): 184-90, 2016.

38- XIN C., LIU J., ZHANG J., ZHU D., WANG H., XIONG L., LEE Y., YE J., LIAN K., XU C., ZHANG L., WANG Q., LIU Y. and TAO L.: Irisin improves fatty acid oxidation and glucose utilization in type 2 diabetes by regulating the AMPK signaling pathway. Int. J. Obes. (Lond). 40 (3): 443-51, 2016. 
39- WU H., DENG X., SHI Y., SU Y., WEI J. and DUAN H.: PGC-1 $\alpha$, glucose metabolism and type 2 diabetes mellitus. J. Endocrinol., 229: R99-R115, 2016.

40- LEE H.J., LEE J.O., KIM N., KIM J.K., KIM H.I., LEE Y.W., KIM S.J., CHOI J., OH Y., KIM J.H., HWANG S., PARK S.H. and KIM H.S.: Irisin, a Novel Myokine, Regulates Glucose Uptake in Skeletal Muscle Cells via AMPK. Mol. Endocrinol., 29 (6): 873-81, 2015.

41- HOU N., DU G., HAN F., ZHANG J., JIAO X. and SUN X.: Irisin Regulates Heme Oxygenase-1/Adiponectin Axis in Perivascular Adipose Tissue and Improves Endothelial Dysfunction in Diet-Induced Obese Mice. Cell Physiol. Biochem., 42 (2): 603-14, 2017.

42- ZHAO L., FU Z., WU J., AYLOR K.W., BARRETT E.J., CAO W. and LIU Z.: Globular adiponectin ameliorates metabolic insulin resistance via AMPK-mediated restoration of microvascular insulin responses. J. Physiol., 593 (17): 4067-79, 2015.

43- ERGUN A., KOSE S.K., AYDOS K., ATA A. and AVCI A.: Correlation of seminal parameters with serum lipid profile and sex hormones. Arch. Androl., 53 (1): 21-3, 2007.

44- SAEZ-LANCELLOTTI T.E., BOARELLI P.V., MONCLUS M.A., CABRILLANA M.E., CLEMENTI M.A. and ESPINOLA L.S.: Hypercholesterolemia impaired sperm functionality in rabbits. PLoS One, 5 (10): ee13457, 2010.

45- OELMANN S., NAUCK M., VÖLZKE H., BAHLS M. and FRIEDRICH N.: Circulating Irisin Concentrations Are Associated with a Favourable Lipid Profile in the General Population. LoS One, 11 (4): e0154319, 2016.

46- CODONER-FRANCH P., TAVREZ-ALONSO S., MURRIA-ESTAL R., MEGAS-VERICAT J., TORTAJADAGIRBÉS M. and ALONSO-IGLESIAS E.: Nitric oxide production is increased in severely obese children and related to markers of oxidative stress and inflammation. Atherosclerosis, 215: 475-80, 2011.

47- FARIAS J.G., PUEBLA M., ACEVEDO A., TAPIA P.J., GUTIÉRREZ E. and ZEPEDA A.: Oxidative stress in rat testis and epididymis under intermittent hypobaric hypoxia: Protective role of ascorbate supplementation. J. Androl., 31: 314-21, 2010

48- PALMEIRA C.M., ROLO A.P., BERTHIAUME J., BJORK J.A. and WALLACE K.B.: Hyperglycemia decreases mitochondrial function: The regulatory role of mitochondrial biogenesis. Toxicology and Applied Pharmacology, 225: 214-20, 2007

49- DOHLE G.R., DIEMER T., GIWERCMAN A., JUNGWIRTH A., KOPA Z. and KRAUSZ C.: EAU Guidelines on male infertility, 62: 324-32, 2012
50- HENKEL R.R.: Leukocytes and oxidative stress: Dilemma for sperm function and male fertility. Asian J. Androl., 13 (1): 43-52, 2011.

51- IOMMIELLO V.M., ALBANI E., ROSA A.D., MARRAS A., MENDUNI F., MORREALE G., LEVI S.L., PISANO B. and LEVI-SETTI P.E.: Ejaculate Oxidative Stress Is Related with Sperm DNA Fragmentation and Round Cells. International Journal of Endocrinology, 2015: 321901, 2015 .

52- IBRAHIM M., ASALAH A.K.H., ABD-ALALEEM D.I. and MOURSI S.M.: Effect of Ghrelin on Testicular Functions in Streptozotocin Induced Type 1 Diabetic Rats. International Journal of Diabetes Research, 2 (6): 101$11,2013$.

53- LU J., XIANG G., LIU M., MEI W., XIANG L. and DONG J.: Irisin protects against endothelial injury and ameliorates atherosclerosis in apolipoprotein E-Null diabetic mice. Atherosclerosis, 243: 438-48, 2015.

54- LIU S., DU F., LI X., WANG M., DUAN R., ZHANG J., WU Y. and ZHANG Q.: Effects and underlying mechanisms of irisin on the proliferation and apoptosis of pancreatic 3 cells. PLoS ONE, 12 (4): e0175498, 2017.

55- ABD EL SAMAD A.A.: Role of aminoguanidine on the testis of streptozotocin-induced diabetic albino rat, a light and electron microscopic study. J. Histol., 33: 451-66, 2013.

56- MAZUR-BIALY A.I., BILSKI J., POCHEC E. and BRZOZOWSKI T.: New insight into the direct anti-inflammatory activity of a myokine irisin against proinflammatory activation of adipocytes. Implication for exercise in obesity. Journal Of Physiology and Pharmacology, 68 (2): 243-51, 2017.

57- HAS SAN A., SULAIL F., MANSOUR P., HAMED H.A., EHSAN R.A. and MOHAMMAD A.: A glance at the therapeutic potential of irisin against diseases involving inflammation, oxidative stress, and apoptosis: An introductory review. Pharmacological Research, 129: 44-55, 2018.

58- XIE C., ZHANG Y., TRAN T., WANG H., LI S., GEORGE E.V., ZHUANG H., ZHANG P., KANDEL A., LAI Y., TANG D., REEVES W.H., CHENG H., DING Y. and YANG L.J.: Irisin controls growth, intracellular Ca signals, and mitochondrial thermogenesis in cardiomyoblasts. PLoS One, 10 (8): e0136816, 2015.

59- MARQUEZ B., IGNOTZ G. and SUAREZ S,S.: Contributions of Extracellular and Intracellular $\mathrm{Ca}{ }^{2}+$ to Regulation of Sperm Motility: Release of Intracellular Stores Can Hyperactivate CatSper1 and CatSper2 Null Sperm. Dev. Biol., 303 (1): 214-21, 2007. 


\section{دور الإيريسين فى تعديل وظائف الخصية الهية

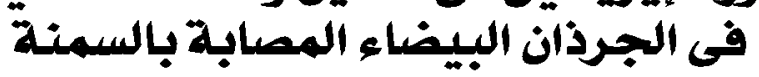

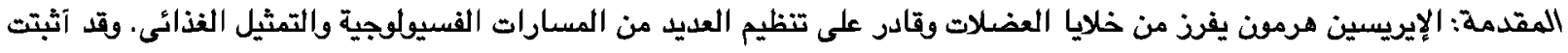

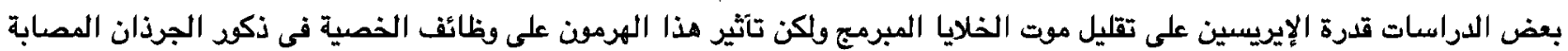
بالسمنة يحتاج إلى دراسة.

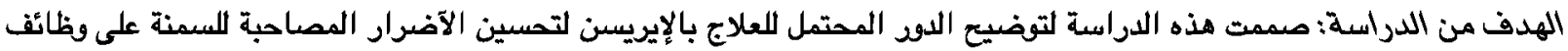

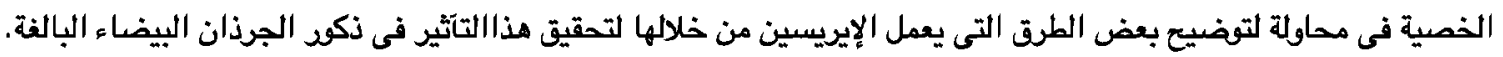

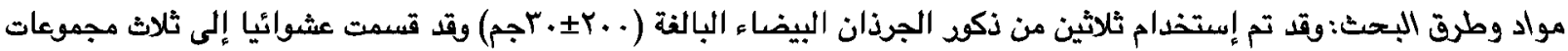

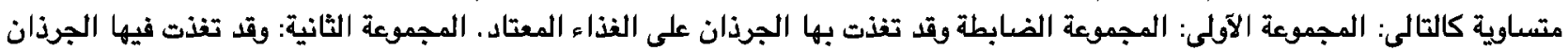

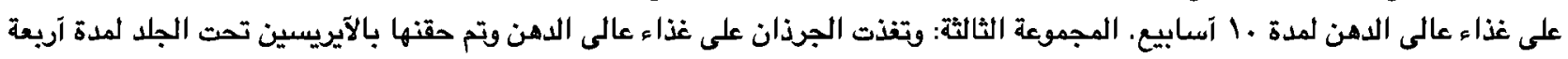

ا - تم ونت الجرذان وقياس مستوى السكر والآتسولين والدهون FSH واللونتين والإستراديول والتستستيرن فى مصل الدم. كما تم تقييم

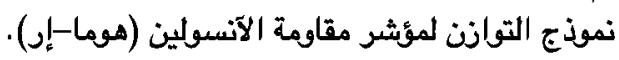

Y- بالإضافة إلى تعيين ونن الخصية وفنن الدهون المحيطة بالبريخ مع حساب عدد الحيوانات المنوية ونسبة الحركة بها فى عينة من منى البريخ. ب- وقد تم آيضا قياس إنزيمات الآكسدة ومضادات الاكسدة فى آنسجة الخصية وهى المالونداهيد وفوق آكسيد الديسموتاز والكتاليز وبروكسيد الجلوتاثيون.

$$
\text { ع- وقد تم عمل مقاطع هستولوجية للخصية فى الجرذان لكل مجموعات الدراسة. }
$$

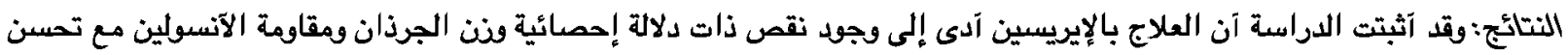

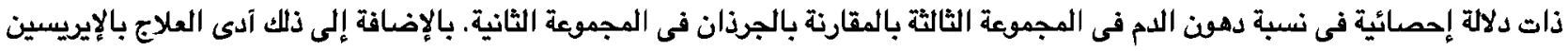

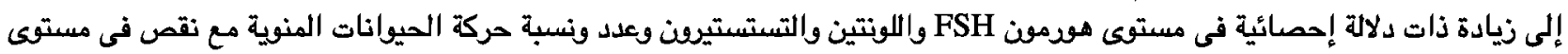

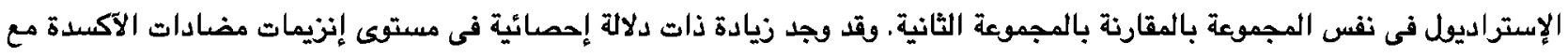
نقص في إنزيمات الآكسدة فى آنسجة الخصية لنفس المجموعة وآكت الدراسات الهستولونية لآلآنسجة الخصية هذا التحسن فى تركيب الآنسجة والخلايا لهذه الجرذان.

الخلاصة: يمكن آن يكون للآيريسين هورمون دود إيجابى ضد الآثار الضارة اللسمنة على وظائف وتكوين الخصية. وقد يكون هذا التآثير

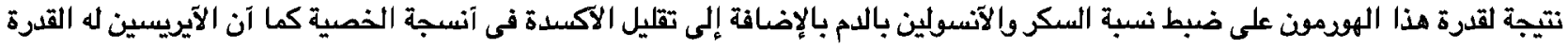

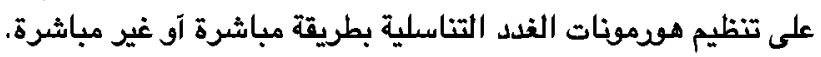

